\title{
BESARNYA MANFAAT DOKUMENTASI PADA ASUHAN KEPERAWATAN
}

\author{
Julia rahma/191101040 \\ emasurya123emasurya123@gmail.com
}

\begin{abstract}
ABSTRAK :
Latar belakang : Dokumentasi merupakan aspek penting dari praktik keperawatan. sistem dokumentasi yang ideal harus memberikan informasi klien yang komprehensif, menunjukkan hasil dan standar klien, manfaat dokumentasi sebagai media untuk mendefinisikan fokus keperawatan bagi klien dan kelompok. Untuk membedakan tanggung gugat perawat dengan anggota tim kesehatan lainnya. Sebagai sarana untuk melakukan evaluasi terhadap tindakan yang telah diberikan kepada klien. banyak perawat yang tidak patuh mendokumentasikan asuhan keperawatan maka akan semakin tinggi resiko terjadinya kesalahan dalam pemberian asuhan keperawatan, semakin kurang bukti pertanggung jawab dan pertanggung gugat perawat, Sehingga Perawat harus mengatahui dan memahami besarnya manfaaat dari dokumentasi asuhan keperawatan. Tujuan : untuk menjelaskan serta memberitahukan kepada mahasiswa keperawatan besarnya manfaat dari melakukan dokumentasi dalam setiap melakukan asuhan keperawatan. Metode : Jurnal ini menggunakan metode tersearch dan analisis dari berbagai sumber seperti buku teks, buku referensi jurnal dan e-book, dan juga di bandingkan dengan jurnal yang berhubungan dengan manfaat dokumentasi keperawatan dalam asuhan keperawatan. Hasil : Dari hasil perbandingan jurnal dokumentasi asuhan keperawatan merupakan bagian penting dari kegiatan yang harus dikerjakan oleh perawat setelahmemberi asuhan kepada pasien. Dokumentasi sebagai suatu sarana informasi yang lengkap dari status kesehatan pasien, kegiatan asuhan keperawatan, kebutuhan fisik mau pun sosial pasien serta respons pasien terhadap tindakan asuhan yang telah di berikan. Kesimpulan : Dokumentasi asuahn keperawatan yang dilakukan perawat memiliki manfaat yang besar bagi fasilitas pelayanan kesehatan, perawat, serta klien. Jika perawat selalu melakukan pendokumentasian asuhan keperawatan, perawat bisa mendapatkan perlindungan dari hukum, perawat juga dapat meningkatkan pengetahuan komunikasi dan dapat memberikan jaminan mutu, akreditas, keuangan yang terjaga di fasilitas pelayanan kesehatan.

Kata Kunci : Manfaat Dokumentasi, Dokumentasi Keperawatan, Asuhan Keperawatan
\end{abstract}




\section{PENDAHULUAN}

Perawat merupakan unsur vital dalam sebuah Rumah Sakit karena perawat merupakan penjalin kontak pertama dan terlama dengan pasien khususnya pasien rawat inap, dengan tugas utama perawat adalah memberikan asuhan keperawatan dari pengkajian, penegakan diagnose keperawatan, intervensi, implementasi sampai dengan evaluasi (Potter \& Perry, 2009). Asuhan keperawatan merupakan satu metode ilmiah dalam penyelesaian masalah klien.

Dokumentasi merupakan aspek penting dari praktik keperawatan. sistem dokumentasi yang ideal harus memberikan informasi klien yang komprehensif, menunjukkan hasil dan standar klien (Twardon dan Gartner, 1993) . Dokumentasi berfungsi sebagai instrument komunikasi meliputi status, kebutuhan, dan kegiatan askep yang telah dilakukan dan direncanakan untuk pasien tersebut.

Dokumentasi keperawatan mempunyai makna penting dalam aspek hukum, kualitas pelayanan, komunikasi, pendidikan, penelitian, dan akreditasi. Berkaitan dengan perlindungan hukum, dokumentasi asuhan keperawatan dapat memberi bukti yang berharga tentang kondisi pasien dan pengobatannya dan dapat bersifat kritis dalam menentukan standar perawatan apakah telah dipenuhi atau tidak (Nursalam, 2008).

Dokumentasi asuhan keperawatan merupakan bagian penting dari kegiatan yang harus dikerjakan oleh perawat setelah memberi asuhan kepada pasien. Dokumentasi sebagai suatu sarana informasi yang lengkap dari status kesehatan pasien, kegiatan asuhan keperawatan, kebutuhan fisik mau pun sosial pasien serta respons pasien terhadap tindakan asuhan yang telah di berikan. Dokumentasi keperawatan memiliki porsi dari catatan klinis pasien yang dapat memberikan informasi faktor tertentu atau situasi yang terjadi selama asuhan dilaksanakan. Catatan pasien sebagai dokumen legal yang berisikan status sehat sakit pasien pada saat lampau maupun sekarang, dituliskan perawat pada saat pengkajian dalam bentuk tulisan, yang dapat memberi suatu gambaran asuhan keperawatan yang akan diberikan. Manfaat dan pentingnya dokumentasi keperawatan mempunyai makna yang penting bila dilihat dari berbagai aspek : Hukum Menurut Nursalam (2008), Dokumentasi keperawatan yang dibuat merupakan aspek legal didepan hukum. Dokumentasi sebagai bukti catatan dari tindakan telah perawat berikan dan untuk dasar bagi pasien, perawat serta institusi untuk berlindung. Sehingga bila terjadi suatu masalah yang tidak diharapkan yang berhubungan dengan profesi keperawatan, harus disertai dengan adanya dokumentasi yang baik dan benar 
Dokumentasi keperawatan menggambarkan keadaan perkembangan pasien, mendokumentasikan asuhan keperawatan yang telah diberikan dan mendokumentasikan asuhan keperawatan untuk masa yang akan datang. Pendokumentasian menjadi media komunikasi yang efektif antara profesi dalam satu tim pelayanan kesehatan. Pendokumentasian asuhan keperawatan bukan hanya sekedar menuliskan sesuatu dalam lembar dokumentasi, tetapi sebelum didokumentasikan harus dianalisis apa yang akan didokumentasikan, bagaimana penyusunan kalimatnya dan dimana tulisan tersebut diletakkan (Rubbenfels \& Scheffer,1999 dalam Hariyati, 2007).

\section{TUJUAN}

Tujuan dari penulisan kajian ini yaitu untuk menjelaskan serta memberitahukan kepada mahasiswa keperawatan besarnya manfaat dari melakukan dokumentasi dalam setiap melakukan asuhan keperawatan.

\section{METODE}

Jurnal ini menggunakan metode tersearch dan analisis dari berbagai sumber seperti buku teks, buku referensi jurnal dan e-book, dan juga di bandingkan dengan jurnal yang berhubungan dengan manfaat dokumentasi keperawatan dalam asuhan keperawatan.

\section{HASIL}

Dokumentasi proses asuhan keperawatan merupakan tampilan perilaku atau kinerja perawat pelaksanan dalam memberikan proses asuhan keperawatan kepada pasien selama pasien dirawat di rumah sakit. Kualitas pendokumentasian keperawatan dapat dilihat dari kelengkapan dan keakuratan menuliskan proses asuhan keperawatanyang diberikan kepada pasien, yang meliputi pengkajian, diagnosa keperawatan, rencana tindakan dan evaluasi (Nursalam,2007).

Manfaat Pendokumentasian sebagai dokumen yang sah, sebagai sarana komunikasi antara tenaga kesehatan, sebagai dokumen yang berharga untuk mengikuti perkembangan dan evaluasi pasien, sebagai sumber data yang penting untuk penelitian dan pendidikan, sebagai suatu sarana bagi bidan dalam pernanannya sebgai pembela (advocate) pasien, misalnya dengan catatan yang teliti pada penkajian dan pemeriksaan awal dapat membantu pasien misalnya pada kasus pengamiayaan, pemerkosaan, yang dapt membantu polisi dalam pengusutan dan pembuktian.

\section{PEMBAHASAN}


Dokumentasi Asuhan Keperawatan merupakan informasi tertulis tentang status dan perkembangan kondisi klien serta semua kegiatan asuhan keperawatan yang dilakukan oleh perawat (Fisbach,1991). Nursalam (2008) menyebutkan instrument studi dokumentasi penerapan standar asuhan keperawatan di RS menggunakan instrument A dari DEPKES (1995) yang meliputi standar I (Pengkajian Keperawatan), standar II (Diagnosa Keperawatan) ,standar III (Perencanaan Keperawatan), standar IV (Intervensi Keperawatan), standar V Evaluasi Keperawatan), standar VI (Catatan Asuhan Keperawatan). Komponen dokumentasi asuhan keperawatan meliputi komponen isi dokumentasi dan komponen dalam konsep penyusunan dokumentasi. Komponen isi dokumentasi meliputi: pengkajian, diagnosis keperawatan, rencana keperawatan, pelaksanaan tindakan keperawatan, evaluasi, pengesahan (tanda tangan/paraf dan nama terang perawat), dan catatan keperawatan diisi secara lengkap dan jelas, resume keperawatan (Catatan pasien pulang atau meninggal dunia) Standar asuhan keperawatan diberlakukan di seluruh rumah sakit melalui Surat keputusan direktur jenderal pelayanan medik nomor: YM.00.03.2.6.7637 tahun 1993 tentang berlakunya standar asuhan keperawatan di rumah sakit.

Menurut Serri (2010) manfaat dokumentasi keperawatan yaitu :

a. Bernilai hukum yaitu dokumentasi keperawatan dapat dijadikan sebagai bukti dalam persoalan yang berhubungan dengan pelayanan kesehatan yang diberikan.

b. Kualitas pelayanan yaitu memberi kemudahan dalam menyelesaikan masalah pelayanan kesehatan sehingga tercapai pelayanan kesehatan yang berkualitas.

c. Sebagai alat komunikasi yaitu sebagai alat perekam terhadap masalah yang berkaitan dengan klien.

d. Terhadap keuangan yaitu sebagai acuan atau pertimbangan dalam biaya perawatan terhadap klien.

e. Terhadap pendidikan yaitu sebagai bahan atau referensi pembelajaran.

f. Terhadap penelitian yaitu sebagai bahan atau objek riset dalam pengembangan profesi keperawatan.

g. Untuk akreditas sebagai acuan untuk mengetahui sejauh mana peran dan fungsi perawat dalam memberikan asuhan keperawatan kepada klien.

Selain itu, manfaat dari dokumentasi keperawatan, antara lain : 
1) Aspek Administrasi

Dilihat dari aspek administrasi dokumentasi mempunyai manfaat untuk mencatat, dikarenakan berkas yang didokumentasikan memiliki nilai identitas, tanggal masuk, dan keluar serta data akses.

2) Aspek Hukum

Dari aspek hukum dokumentasi memiliki manfaat sebagai alat bukti yang sah, isi dari berkas yang berhubungan dengan jaminan kepastian hukum atas dasar keadilan yang berlangsung.

3) Aspek Pendidikan

Suatu informasi atau berkas jika didokumentasikan bermanfaaat untuk mendukung kegiatan pembelajaran, isi dari informasi berkaitan dengan data tentang kronologis perkembangan pelayanan kebidanan yang sudah di berikan kepada pasien.

4) Aspek Penelitian

Ditinjau dari aspek penelitian dokumentasi mempunyai manfaat sebagai penyedia informasi untuk kebutuhan penelitian. Data atau informasi yang terlampir didalam sebuah berkas bisa digunakan untuk kepentingan penelitian dalam mengembangkan ilmu pengetahuan dibidang kesehatan.

\section{5) Aspek Ekonomi}

Suatu informasi atau data memiliki manfaat untuk mendokumentasikan besarnya dana yang harus dikeluarkan, sehingga mengurani terjadinya pemborosan, isi dari sebuah berkas bisa dijadikan bahan untuk menentukan pembayaran pelayanan di sebuah institusi, maka pembayaran atas tindakan tersebut tidak dapat dipertanggung jawabkan.

6) Aspek Manajemen

Informasi yang lengkap dan di simpan dengan benar menunjukkan adanya manajemen yang benar. Suatu berkas dokumentasi adalah semua arus data dan informasi dalam sistem informasi. Berkas ini di manfaatkan dalam melaporkan dan menyusun program pelaksanaan keputusan pimpinan

(Nursalam (2008) menyebutkan Instrumen studi dokumentasi penerapan standar asuhan keperawatan meliputi :

Standar I : Pengkajian keperawatan

Standar II : Diagnosa keperawatan 
Standar III : Perencanaan keperawatan

> Standar IV : Implementasi keperawatan

> Standar V : Evaluasi keperawatan

Standar VI : Catatan asuhan keperawatan.

Dalam pendokumentasian keperawatan ada 3 teknik yang dipakai, yaitu :

I. Teknik naratif, pencatatan tradisonal dan dapat bertahan paling lama serta merupakan system pencatatan yang fleksibel.

II. Teknik flowsheet (bentuk grafik), cara tercepat dan paling efisien untuk mencatat informasi

III. Teknik checklist, tinggal mengisi item yang sesuai dengan keadaan pasien dengan cara mencentang kondisi yang sesuai dengan pasien.

Standar dokumentasi asuhan keperawatan menurut DEPKES (1995) adalah sebagai berikut (Nursalam, 2011): Standar Dokumentasi Asuhan Keperawatan

\section{PENGKAJIAN}

a. Mendokumentasikan data yang dikaji sesuai dengan pedoman pengkajian

b. Data dikelompokkan (bio-psiko-sosio-spritual)

c. Data dikaji sejak klien mulai masuk sampai pulang

d. Masalah dirumuskan berdasarkan masalah kesenjangan antara status kesehatan dengan norma dan pola fungsi kehidupan

\section{DIAGNOSIS}

a. Diagnosis keperawatan berdasarkan masalah yang telah dirumuskan

b. Diagnosis keperawatan mencerminkan PE/PES

c. Merumuskan diagnosis keperawtan aktual/potensial.

\section{PERENCANAAN}

a. Berdasarkan diagnosis keperawatan

b. Disusun menurut urutan prioritas

c. Rumusan tujuan mengandung komponen klien/subjek, perubahan, perilaku, kondisi klien, dan atau kriteria.

d. Rencana intervensi mengacu pada tujuan dengan kalimatperintah, terinci, dan jelas, dan atau melibatkan klien/keluarga

e. Rencana intervensi menggambarkan keterlibatan klien/keluarga 
f. Rencana intervensi menggambarkan kerja sama dengan tim kesehatan lain.

\section{INTERVENSI}

a. Intervensi dilaksanakan mengacu pada rencana asuhan keperawatan

b. Perawat mengobservasi respon klien terhadap intervensi keperawatan

c. Revisi intevvensi berdasarkan hasil evaluasi

d. Semua intervensi yang telah dilaksanakan didokumentasikan dengan ringkas dan jelas.

\section{EVALUASI}

a. Evaluasi mengacu pada tujuan

b. Hasil evaluasi didokuemntasikan

\section{CATATAN ASUHAN KEPERAWATAN}

a. Menulis pada format yang baku

b. Pendokumentasian dilakukan sesuai dengan intervensi yang dilaksanakan

c. Pendokumentasian ditulis dengan jelas, ringkas, istilah yang baku dan benar.

d. Setiap melakukan intervensi/kegiatan perawat mencantumkan paraf dan nama dengan jelas, serta tanggal dan waktu dilakukannya intervensi.

e. Berkas catatan keperawtan disimpan dengan ketentuan yang berlaku.

\section{KESIMPULAN}

Pendokementasian Asuhan keperawatan merupakantugas yang wajib bagi setiap perawat, perawat wajib melakukan pengkajian baik saat diberikannya tidakan ataupun sesudah adanya hasil dari tindakan yang diberikan kepada klien.

Dokumentasi asuahn keperawatan yang dilakukan perawat memiliki manfaat yang besar bagi fasilitas pelayanan kesehatan, perawat, serta klien. Jika perawat selalu melakukan pendokumentasian asuhan keperawatan, perawat bisa mendapatkan perlindungan dari hukum, perawat juga dapat meningkatkan pengetahuan komunikasi dan dapat memberikan jaminan mutu, akreditas, keuangan yang terjaga di fasilitas pelayanan kesehatan.

\section{REFERENSI}

Ali, Z. (2009). Dasar-Dasar Dokumentasi Keperawatan. Jakarta : EGC.

Dalami, E. (2011). Dokumentasi Keperawatan Dengan Kurikulum Berbasis Kompetensi. Jakarta : Trans Info Media Enny Nurcahyani, 
Enny., Widodo, Dyah., Rosdiana, Yanti. (2016). Hubungan Tingkat Stres Kerja Dengan Kinerja Perawat. Jurnal Care. 4 (1), 42-48.

Hutahaean, Serri. (2010). Konsep dan Dokumentasi Proses Keperawatan. Jakarta: Trans Info Media.

Nursalam.( 2007). Manajemen Keperawatan, Aplikasi dan Praktik Keperawatan. Jakarta: Salemba Medika.

Potter \& Perry. (2009). Fundamental Keperawatan. Edisi 7. Jakarta : Salemba Medika

Purwanti. E. (2012). Asuhan Kebidanan Untuk Ibu Nifas. Yogyakarta : Cakrawala Ilmu.

Rosdahl, Caroline Bunker. (2014). Buku Ajar Keperawatan Dasar. Jakarta : EGC.

Setiadi. (2012). Konsep \& Penulisan Dokumentasi Asuhan Keperawatan; Teori dan Praktik. Yogyakarta : Graha Ilmu

Simamora, R. (2009). Dokumentasi Proses Keperawatan.

Simamora, R. H., Purba, J. M., Bukit, E. K., \& Nurbaiti, N. (2019). Penguatan Peran Perawat Dalam Pelaksanaan Asuhan Keperawatan Melalui Pelatihan Layanan Prima. JPPM (Jurnal Pengabdian Dan Pemberdayaan Masyarakat), 3(1), 25-31.

Susanto, Rachmat. (2010). Penerapan Standar Proses Keperawatan Di Puskesmas Rawat Inap Cilacap. Jurnal Keperawatan Soedirman (The Soedirman Journal of Nursing). 5(2),80- 84.

Toha, M. (2008). Perilaku Organisasi: Konsep dasar dan aplikasinya. Jakarta: Raja Grafindo Persada. 